\title{
CONCRETE-LIKE TILL: A SCIENTIFIC AND ECONOMIC PROBLEM
}

\author{
JARI NENONEN, PETER JOHANSSON, ESKO KONTAS, ESKO KORKIAKOSKI, \\ MIKKO KVIST and SEPPO ROSSI
}

\begin{abstract}
NENONEN, JARI, JOHANSSON, PETER, KONTAS, ESKO, KORKIAKOSKI, ESKO, KVIST, MIKKO and ROSSI, SEPPO 2000. Concrete-like till, a scientific and economic problem. Bulletin of the Geological Society of Finland 72, Parts 1-2, 87-96.

In Finland, extremely compact and hard, concrete-like basal till, a type rare to the country, occurs in the district of Haukipudas on the coast of Northern Ostrobothnia. The cause of cementation is not its age but rather the composition of the underlying bedrock, which consists of pyrrhotite- and pyrite-bearing black schists. During intense erosion under the ice sheet, a large amount of material derived from this was released into the overlying basal till. Rapid oxidation of sulphide grains in the till began as a consequence of uplift of the area above sea level and the lowering of the groundwater surface. Sulphide was oxidised to sulphate and ferrous iron became ferric, which precipitated as ferric hydroxide. As this initially water-rich gel-like ferric hydroxide formed, it enclosed the till clasts and mineral grains. With water loss it hardened and cemented the till into a concrete-like mass.
\end{abstract}

Key words: till, lodgement till, black schists, sulfides, oxidation, iron, hydroxides, cementation, water table, drawdown, Haukipudas, Finland

Jari Nenonen, Peter Johansson, Esko Kontas, Esko Korkiakoski, Mikko Kvist and Seppo Rossi: Geological Survey of Finland, P.O. Box 77, FIN-96101 Rovaniemi, Finland

\section{INTRODUCTION}

In 1993-1998, during investigations related to ore prospecting north and northeast of the village of Haukipudas in Northern Ostrobothnia, Finland, a layer of extremely hard basal till, a till type rare in that country, was found (Fig. 1). This impeded both the removal of till deposits from the bedrock surface by excavator and the realignment through the area of Highway 4, which was then in progress. The hardness of the till layer is reflected by the fact that the heavy excavators used in the road work broke down and that the till masses could only be loosened by blasting. The till cementation problem caused many difficulties in the geochemical sampling of till, often an integral part of ore exploration. The schedule for this was delayed and in places samples could only be taken with heavy drilling equipment. A similar concretelike till deposit was found during ore prospecting by Quaternary-geological methods in the Vepsä area, southeast of Ylikiiminki.

The purpose of this study is to describe the conditions related to the occurrence of the concretelike till in terms of stratigraphy, its mineral composition and its relationship to postglacial marine 


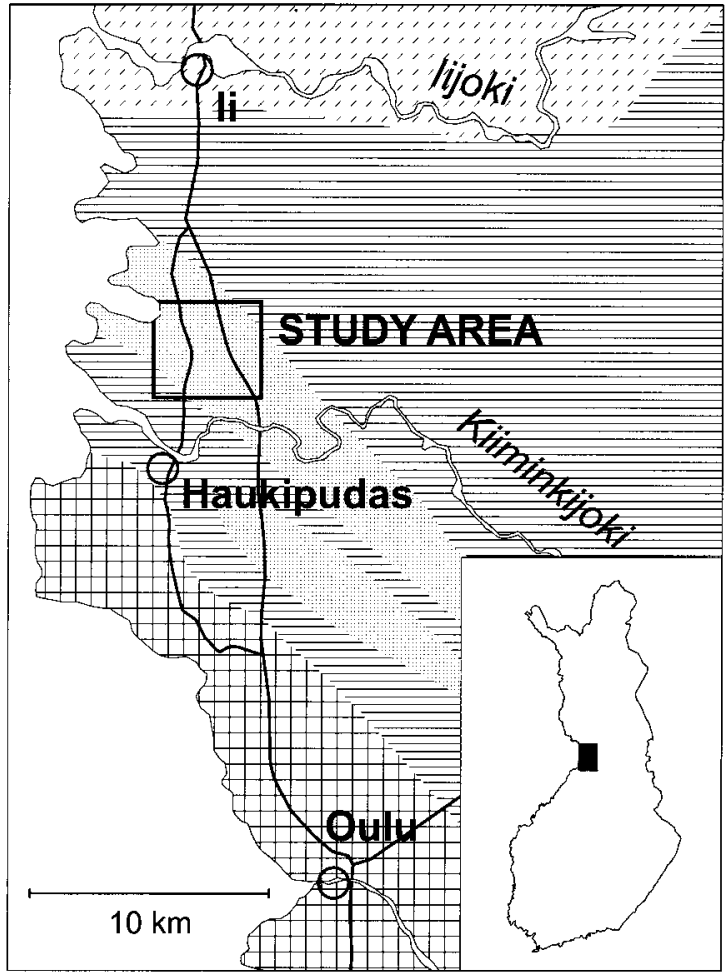

1
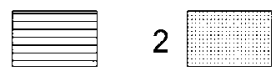

3
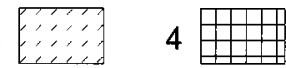

Fig. 1. Location and bedrock of the study area. $1=$ mica schist; 2 = black schist; 3 = Archaean basal gneiss; 4 = Muhos claystone. Simplified from Honkamo (1989).

stages, and to clarify those factors which cause this phenomenon in till. Based on these results, it may be possible to direct investigations towards more easily excavated areas, so either avoiding the extra costs incurred by the concrete-like till or taking the costs of its removal into account. For example, such information may be important in the planning new neighbourhoods, roads or other structures for the surroundings of the city of Oulu.

\section{GEOLOGICAL SETTING}

\section{Bedrock}

The study area is a part of the Northern Ostrobothnian Schist Area, which extends from Haukipudas in the northwest to Utajärvi in the southeast. The area is characterized by extensive fine- and medium-grained turbiditic metasediments (mica schists) with coarse-grained, conglomeratic intercalations locally. Other rock types typical of the schist area are sulphide-bearing black schists and related basic metavolcanic rocks, which together make up about $10 \%$ of the area. In addition there are lesser amounts of skarn, chert and dolostone (Honkamo 1986). To the north and east the schist area is bounded by Archaean basal gneisses. To the south there are younger granitoids and the Muhos claystone formation (Fig. 1). In terms of ore geology, the rocks of the Northern Ostrobothnian Schist Area resemble those related to the Hammaslahti $\mathrm{Cu}$ $(\mathrm{Zn})$ ore, eastern Finland, and the ore deposits of the Vihanti area, about $120 \mathrm{~km}$ south of Oulu. The ore potential of the area is also indicated by several known mineralized localities and $\mathrm{Pb}-\mathrm{Zn}$-Cu-bearing boulders (Korkiakoski et al. 1995).

\section{Quaternary deposits}

The Haukipudas area emerged from under the melting ice sheet about 9000 years ago. However, for thousands of years, it was submerged under the Ancylus Lake and the Litorina Sea stages of the ancient Baltic Sea. As a consequence of land uplift, the area emerged above the surface of the Gulf of Bothnia as late as at the beginning of the Christian Era. The land along the coast of the Gulf of Bothnia is still rising at a rate of about $7 \mathrm{~mm}$ per year and, consequently, the delta of the River Kiiminkijoki is migrating into the sea at an average rate of $1 \mathrm{~km}$ per century.

The Quaternary deposits of Haukipudas consist mainly of basal till. Fluvial sediments of varying thickness, with fossil dunes and raised beaches, cover the till in the Kiiminkijoki River valley. In this area there are two separate ice-flow directions and corresponding till units of different ages. The till units can be distinguished from each other by their fabric and also by physical properties, such as colour and lithological composition.

The lower till bed is an unstructured, sandy, generally grey basal till. According to the classification system for the physical properties of till 
(classes 1-5) of Hirvas (1991), the till is normal or compact (class 3-4) and it contains slightly rounded clasts (class 2). The humidity, clast frequency and clast size are normal (class 3 ). The elongated clasts of the till are clearly oriented, indicating that the till was deposited from the $320^{\circ}-345^{\circ}$ direction. Its lithological composition is similar to that of the bedrock in the surrounding area, except for some granitic clasts transported farther from the NW. The formation of the till is related to the flow stage of the Early Weichselian ice sheet which in the general till stratigraphy of northern Finland can be correlated with flow stage III of the ice sheet and till bed III deposited by it (cf. Hirvas 1991). The corresponding flow stage and till unit also occur in the Pudasjärvi - Kiiminki area. These are within the Pudasjärvi marginal formation, which has been interpreted as Early Weichselian (cf. Sutinen 1992).

The upper till unit is a mostly brownish grey sandy basal till containing stripes of brown precipitate. The till has normal (class 3) humidity, compactness and clast frequency. The clast size varies between classes 2 and 3 and the boulders are slightly rounded (class 2). The till has a poorly developed lamination that is the result of frost, which can be traced from the surface to a depth of about one metre. The contact between the upper till and the grey, compact till underlying is gradual but clearly visible as a change in compactness. In terms of lithological composition the upper till is more heterogeneous, although the proportion of local rocks is still considerable. The distinct orientation of the elongated clasts within the till indicates flow of the ice sheet from a direction of $280^{\circ}-290^{\circ}$. This sedimentation occurred during the last glaciation stage, i.e. the younger Weichselian, which corresponds to till bed II of Hirvas (1991). A similar younger till unit has also been described by Aario and Forsström (1979), by Sutinen (1992), in till-stratigraphic studies, and by Kurimo (1979) in investigations of ice-flow directions based on drumlin studies. A minor, WNWESE trending esker sequence, Jolosharju, was deposited during the deglaciation stage (Vasunta 1984). There are no other glaciofluvial deposits in the area.

\section{RESEARCH METHODS}

The data were collected in connection with ore prospecting work by the Geological Survey of Finland (GTK) in the area during 1993 and 19951998. The structure and stratigraphic sequence of the Quaternary deposits were studied in pits dug by excavator in those parts of the area where concrete-like till occurs (Fig. 2). Stratigraphic profiles were recorded from the walls of the pits, including visual observations of physical properties and lithological composition of the till. The physical properties of the till, such as, humidity, compactness, clast frequency, size and roundness were divided according to increasing parameters into classes 1-5 (see Maaperäosaston kartoitus- ja tutkimusryhmä 1976). Till fabrics were analysed to establish the ice-flow direction for the till beds and their relative ages. For each till layer analysed, rose diagrams were constructed from the measured orientations of the longitudinal axes of $50-100$ elongated till clasts. The orientation of ice sheet striations were measured to check the results.

Grids of points for sampling of the soil/bedrock by drilling were placed across the earlier located areas of concrete-like till. The heavy drilling equipment allowed continuous sampling of both the till deposits and the underlying bedrock. Samples accurately linked to the till stratigraphy, of both concrete-like till and normal till, were taken from the walls of the mechanically excavated pits.

The chemical composition of the till samples was determined by the chemical laboratory of the GTK in Rovaniemi. The samples were dried at $70^{\circ} \mathrm{C}$ and then, following gentle comminution, the $<0.06 \mathrm{~mm}$ fraction was obtained by sieving. Some till samples were totally crushed for comparison of their element composition with that of the local bedrock. After hot aqua regia leaching at $90^{\circ} \mathrm{C}$, 30 major and trace elements were determined from the till samples by multichannel inductively coupled plasma spectrometer (ICP). To determine the heavy metal concentration and rock composition, samples of about $10 \mathrm{~kg}$ were wet sieved. Heavy material with a grain size less than $2 \mathrm{~mm}$ was concentrated using a spiral concentrator. The composition of this heavy fraction was determined in the 


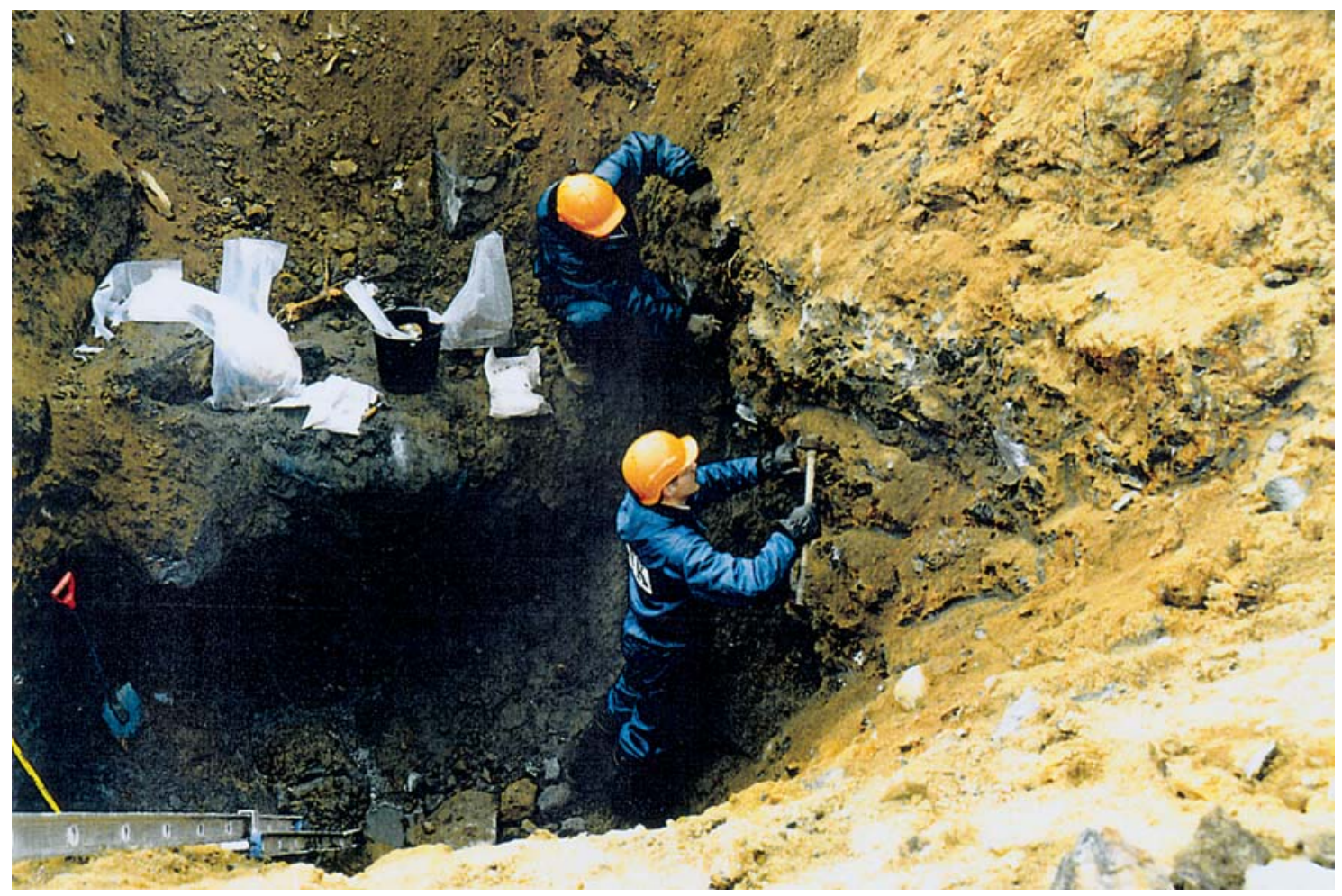

Fig. 2. Sampling of till in a pit dug by excavator.

chemical laboratory of the University of Oulu by AAS. The whole rock composition was determined using the $2-10 \mathrm{~mm}$ rock fragments that remained after seiving.

In the petrological laboratory of the GTK, $\mathrm{x}$ ray diffraction (XRD) determinations were made of the mineral composition of both concrete-like and normal tills. A small sample (about $20 \mathrm{~g}$ ) of the concrete-like till was crushed, and the fines were removed by ultrasonic cleaning. XRD determinations were carried out on both the coarse and the fine residue obtained by ultrasonic cleaning. Thin sections were made for compositional studies of the concrete-like till.

\section{RESULTS}

Concrete-like till occurs in an approximately EW trending zone about four kilometres wide and five kilometres long, north of the village of
Haukipudas. In this area the bedrock comprises pyrrhotite- and pyrite-bearing black schists. The orientation of the schists is the same as the last direction of ice flow in the area $\left(280^{\circ}-290^{\circ}\right)$. The sulphide-bearing black schists cause strong magnetic anomalies and appear as areas of conductivity on low-altitude aerogeophysical maps (Fig. 3).

The till stratigraphy indicates that the concretelike till occurs near the highest points of the moraine hills of the area, which are clearly above the groundwater table. The bed thins out gradually down the hill slopes and disappears near the bogs at the bottoms (Fig. 4). Concrete-like till occurs mostly at a depth of about 1-1.5 m below the surface. Deeper than this, below the groundwater table, the compactness of the till returns to normal. The concrete-like till bed is between 0.5 and 1.5 metres thick and is coloured brown or reddish brown, because it contains numerous stripes of rusty brown precipitate (Fig. 5). Nevertheless, the hard till does not form a uniform bed or layer but 


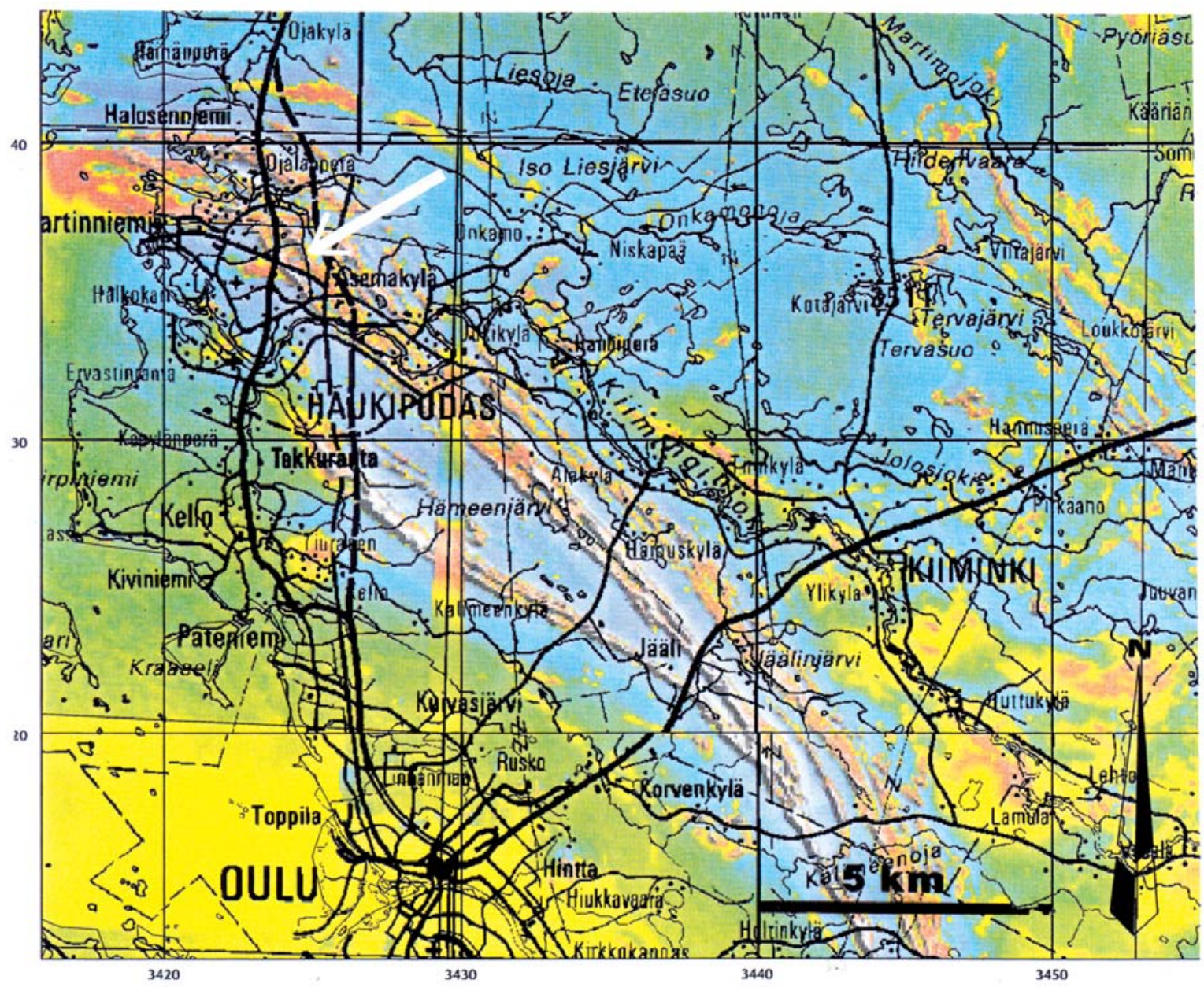

Fig. 3. Aerogeophysical map showing zones of sulphide-bearing black schist. The arrow indicates the study area.

contains patches of grey till of normal compactness. The concrete-like till is an exceptionally compact (class 5) and very dry (class 2) sandy till. Because of its compactness, it is almost impermeable to water. This till does not contain other structures besides the precipitates. The contact between concrete-like till and the underlying till of normal compactness is gradual and contains flame-like, cemented and precipitated structures, which appear to extend downwards to the groundwater table.

Heavy mineral studies indicate that, exceptionally, the till of the area is particularly rich in pyrite and pyrrhotite, which is typical of black schists (Ahtonen 1996). A till sample of 10 litres may contain a maximum of $200 \mathrm{ml}$ of sulphides. There is a clear difference in sulphide concentration between the concrete-like till and the till of normal compactness that is below the groundwater table. Sulphide grains are usually absent from heavy mineral samples of concrete-like till, whereas till of normal compactness contains many sulphide grains.

XRD determinations of the coarse material and fines of the concrete-like till indicate that most common minerals are quartz, potassium feldspar, albite, amphibole, chlorite and micas. One sample also contains gypsum. No difference in mineral composition was observed between till units of different age. The thin sections prepared from the concrete-like till indicate that the matrix, i.e. the material between the small clasts and gravel 
m a.s.l.

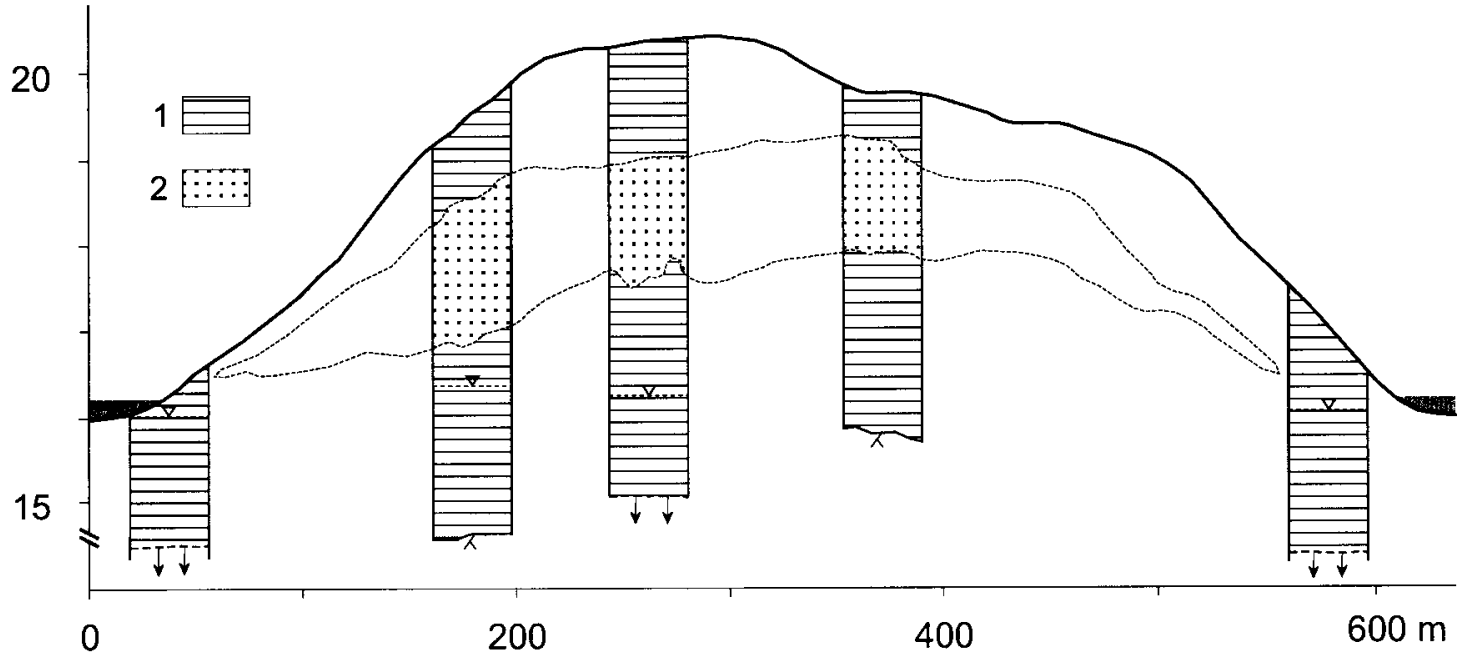

Fig. 4. Schematic diagram of the effect of small-scale morphology on the occurrence of concrete-like till. $1=$ normal till; 2 = concrete-like till layer.

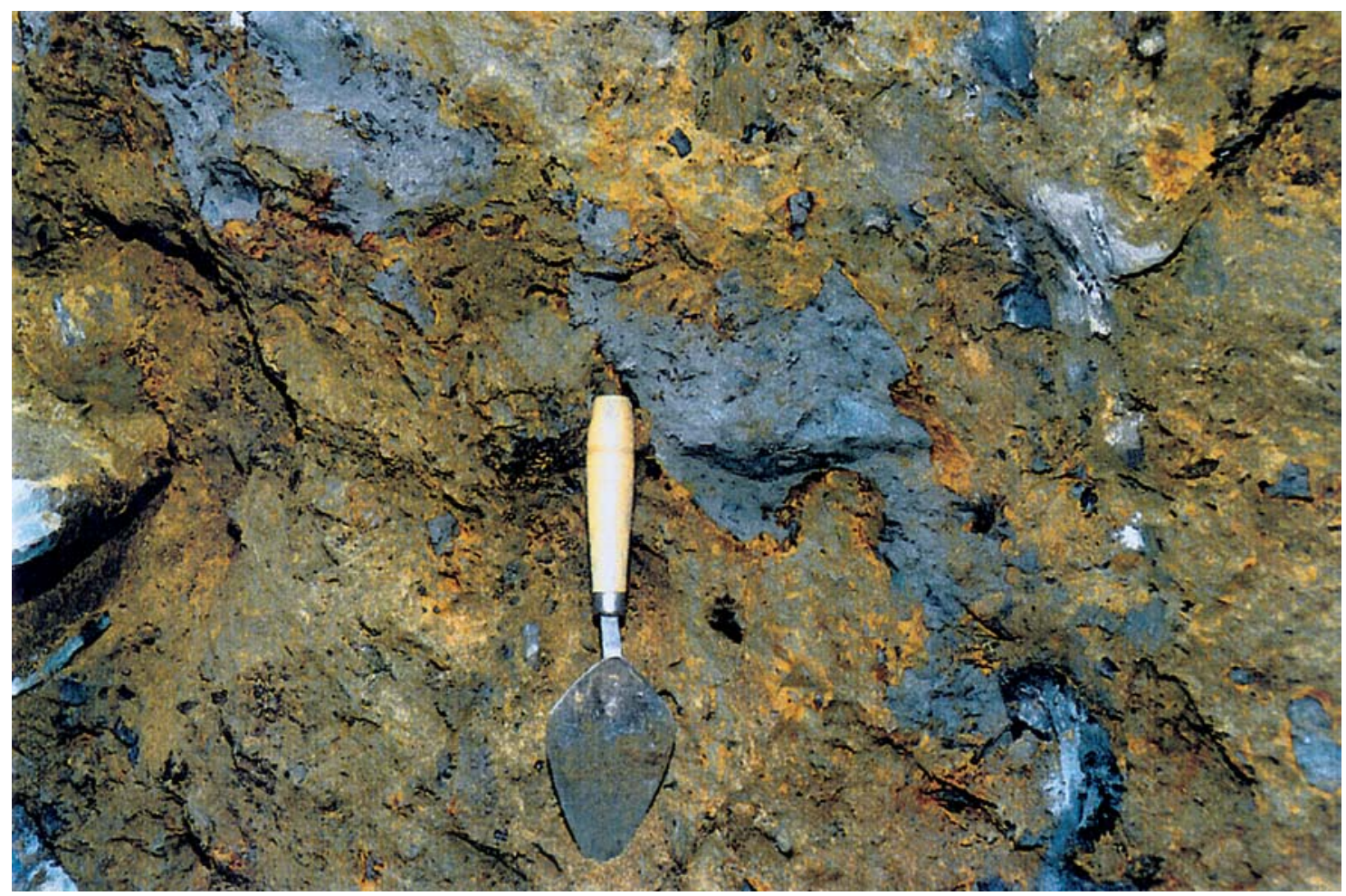

Fig. 5. Photograph from a pit wall showing the distictive brown colour of the cemented, concrete-like till. 
Table 1. Soil/bedrock drilling: Fe and S concentrations in till; total grinding of the sample, hot aqua regia digestion.

\begin{tabular}{|c|c|c|c|c|c|}
\hline \multicolumn{3}{|c|}{ Till of normal compactness } & \multicolumn{3}{|l|}{ Concrete-like till } \\
\hline Sample no/depth $\mathrm{dm}$ & $\mathrm{Fe} \%$ & S ppm & Sample no/depth dm & $\mathrm{Fe} \%$ & S ppm \\
\hline 181512 008MRT & 5,19 & 8160 & 181512 023MRT & 5,37 & 8920 \\
\hline 181512 013MRT & 5,14 & 6370 & 181514 020MRT & 5,2 & 9230 \\
\hline 181512 040MRT & 4,98 & 11200 & 181515 020MRT & 4,82 & 8630 \\
\hline 181515 010MRT & 4,46 & 1850 & 181516 020MRT & 5,54 & 12000 \\
\hline 181515 030MRT & 3,74 & 8680 & & & $\overline{9695=}$ \\
\hline \multirow[t]{2}{*}{181516 030MRT } & 4,69 & 18200 & & & \\
\hline & & $\overline{9076=}$ & & & \\
\hline MEAN \% & 4,7 & 0,91 & & 5,23 & 0,97 \\
\hline
\end{tabular}

Table 2. Soil/bedrock drilling: Fe and S concentrations in till; under 0,006 mm fraction, hot aqua regia digestion.

\begin{tabular}{|c|c|c|c|c|c|}
\hline \multicolumn{3}{|c|}{ Till of normal compactness } & \multicolumn{3}{|l|}{ Concrete-like till } \\
\hline Sample no/ depth dm & $\mathrm{Fe} \%$ & S ppm & Sample no./ depth dm & $\mathrm{Fe} \%$ & S ppm \\
\hline 181509 30MRP & 3,56 & 3840 & 181509 10MRP & 4,29 & 184 \\
\hline 181510 29MRP & 6,88 & 13800 & 181509 20MRP & 3,37 & 681 \\
\hline 181511 10MRP & 7,24 & 5850 & 181510 10MRP & 5,15 & 2020 \\
\hline 181512 47MRP & 4,58 & 9550 & 181510 20MRP & 6,21 & 7040 \\
\hline 181513 30MRP & 4,97 & 12100 & 181511 20MRP & 5,49 & 5880 \\
\hline 181513 40MRP & 5,36 & 10700 & 181511 30MRP & 6,6 & 7160 \\
\hline 181514 10MRP & 6,38 & 6730 & 181511 37MRP & 7,17 & 9180 \\
\hline 181514 40MRP & 5,84 & 9370 & 181513 10MRP & 7,14 & 3940 \\
\hline 181514 53MRP & 4,34 & 10300 & 181513 20MRP & 7,1 & 3390 \\
\hline 181515 40MRP & 3,95 & 6570 & 181514 30MRP & 6,18 & 10100 \\
\hline 181515 53MRP & 3,73 & 8940 & 181517 10MRP & 4,57 & 1840 \\
\hline 181516 40MRP & 3,57 & 13900 & 181517 20MRP & 6,89 & 8840 \\
\hline 181516 46MRP & 3,91 & 18800 & & & $\overline{5021=}$ \\
\hline 181517 30MRP & 7,19 & 15000 & & & \\
\hline 181517 40MRP & 8,37 & 15500 & & & \\
\hline 181518 5MRP & 4,21 & 1550 & & & \\
\hline 181519 10MRP & 4,35 & 3520 & & & \\
\hline \multirow[t]{2}{*}{181519 20MRP } & 5,28 & 5350 & & & \\
\hline & & $\overline{9520=}$ & & & \\
\hline MEAN \% & 5,21 & 0,95 & & 5,84 & 0,50 \\
\hline
\end{tabular}

grains, is formed by grains of quartz, plagioclase, amphibole and opaque minerals, bound together by goethite cement which contains flakes of biotite and muscovite. Opaque minerals, which are scarce in the matrix, comprise pyrite, magnetite and ilmenite. At grain rims there is in places alteration of magnetite into hematite.

The chemical analyses indicate that there are strong contrasts between the sulphur and iron con- centrations of the till (Tables 1-3). The sulphur concentration of the concrete-like till is lower than that of the normal till in the underlying groundwater zone. In contrast, the concrete-like till has a higher Fe concentration. No similar strong correlations were established between other metals. The variations in sulphur concentrations in the till units are probably due to the different internal weathering conditions of their sulphides. 
Table 3. Test pits: Fe and $S$ concentrations in till; under $0.006 \mathrm{~mm}$ fraction, hot aqua regia digestion.

\begin{tabular}{|c|c|c|c|c|c|}
\hline \multicolumn{3}{|c|}{ Till of normal compactness } & \multicolumn{3}{|l|}{ Concrete-like till } \\
\hline Test pit no./ depth $\mathrm{dm}$ & $\mathrm{Fe} \%$ & S ppm & Test pit no./ depth dm & $\mathrm{Fe} \%$ & S ppm \\
\hline 181600005 & 3,41 & 1070 & 181600010 & 3,85 & 1390 \\
\hline 181600028 & 3,78 & 1160 & 181600015 & 4,29 & 3570 \\
\hline 181600030 & 2,48 & 3000 & 181600020 & 5,23 & 3790 \\
\hline 181600035 & 2,87 & 3290 & 181601015 & 3,55 & 533 \\
\hline 181601030 & 4,24 & 255 & 181601020 & 3,69 & 467 \\
\hline 181601035 & 4,59 & 748 & 181601025 & 3,22 & 605 \\
\hline 181601040 & 5,6 & 454 & 181602015 & 4,58 & 861 \\
\hline 181601045 & 2,19 & 4610 & & & $\overline{1602=}$ \\
\hline 181601050 & 2,83 & 6090 & & & \\
\hline 181602008 & 3,05 & 512 & & & \\
\hline 181602022 & 2,53 & 3250 & & & \\
\hline 181603020 & 2,29 & 1300 & & & \\
\hline \multirow[t]{2}{*}{181603030} & 2,55 & 1510 & & & \\
\hline & & $\overline{2096}=$ & & & \\
\hline MEAN \% & 3,33 & 0,21 & & 4,06 & 0,16 \\
\hline
\end{tabular}

DISCUSSION: RESULTS AND FORMATION OF THE CONCRETE-LIKE TILL

There is no evidence that the hardening of the basal till in the study area is dependent on either the age relations of the till units or on compaction under the weight of ice overconsolidation. This is the case in, for example, central and southern Ostrobothnia and in southern Finland, where an ancient till unit, interpreted as dating from the Saale glaciation, is considerably more compact than the overlying till units, which are interpreted as dating from the younger Weichselian glaciation (Nenonen 1995). In the Kaamanen area, in northern Lapland, the pressure exerted by the ice sheet on the till bed caused compaction of the till (Saarenketo \& Tammela 1987). In the study area this phenomenon is seen only in a limited layer at the surface of the till, in both the older and younger till unit.

In both periods of ice sheet flow across the study area it strongly eroded the underlying, evidently already broken bedrock of black schist. The ice sheet blucked off abundant rock material, which became mixed with the till. During the last ice flow stage, in particular, the parallelism of the direction of ice flow with the orientation of the schists further enhanced erosion. Up to $90 \%$ of the material making up the till derives from the local bedrock, which contains abundant pyrrhotite and pyrite. Chemical changes in these minerals caused the cementing phenomenon.

With the sinking of the groundwater table as a consequence of land uplift, pyrrhotite and pyrite came in contact with both atmospheric oxygen and surface water. Especially pyrrhotite, but pyrite as well, are easily oxidised into ferric hydroxide and sulphuric acid.

The ferric hydroxide tends to precipitate and becomes immobile, whereas the sulphuric acid is mainly removed from the system in solution. Ferric hydroxide is poorly soluble, and its precipitation begins with a $\mathrm{pH}$ as low as 2 (Seel 1965). Not even the sulphuric acid formed in situ can prevent it from precipitating. As the ferrihydroxide precipitates it is initially amorphous and contains much water. With time it gradually loses water and finally forms crystalline, dense goethite. The crystallisation is slow and involves many intermediate stages, which are either amorphous or poorly crystalline (Carlson \& Loukola-Ruskeeniemi 1998). This explains why no XRD lines for goethite or other iron oxides were obtained from the concrete-like till, even though the deposit is completely permeated by ferric oxides both macroscopically and microscopically. Besides ferric 
oxide, calcium sulphate, i.e. gypsum $\left(\mathrm{CaSO}_{4}\right)$, which is formed by the reaction between calcium and sulphuric acid, may be another cement mineral. However, only one in ten samples examined by XRD gave a weak gypsum line, which indicates that it is of minor significance in cementation.

In the black schists of the study area, the median concentrations of sulphur and of iron soluble in aqua regia are $10.3 \%$ and $3.9 \%$, respectively (Ahtonen 1996). As part of this study 10 samples of ground whole rock till were analysed, of which four were concrete-like till and six were till of normal compactness (Table 1). The average concentrations of $\mathrm{Fe}$ and $\mathrm{S}$ in the concrete-like till are $5.23 \%$ and $0.97 \%$, respectively, and $4.70 \%$ and $0.91 \%$ in the till of normal compactness. In both till types, compared to the source rock, Fe and $\mathrm{S}$ have been depleted by factors of two and four, respectively.

Because the study was made in connection with ore prospecting, most analyses were performed on the $<0.06 \mathrm{~mm}$ sample fraction. In this fraction, the average $\mathrm{Fe}$ concentrations in concrete-like till samples taken by drilling and from test pits are $5.84 \%$ and $4.06 \%$, respectively, with corresponding $\mathrm{S}$ concentrations of $0.50 \%$ and $0.16 \%$ (Tables 2 and 3 ). The corresponding concentrations in till of normal compactness are (Fe) $5.21 \%$ and $3.33 \%$, and (S) $0.95 \%$ and $0.21 \%$. The Fe concentrations are almost similar to those for the whole rock till, whereas the $\mathrm{S}$ concentrations are lower. This may be due to separation during sieving, however, relative to the source rock, sulphur is clearly more depleted than iron. The average Fe- and S-concentrations in till samples taken from test pits are lower than in those obtained by heavy soil drilling (Tables 2 and 3). This is because in the till samples taken by soil drilling, local boulder material has been crushed during sampling and mixed with the till. This admixture does not occur in samples taken manually from the wall of the test pit.

The compositions of concrete-like till and till of normal compactness are very similar and consequently the formation of concrete-like till may be considered as the result of local conditions. The conditions required for the formation of concrete- like till are a till very rich in iron sulphides and its location above the groundwater table in favourable redox and dry conditions. The ferric hydroxide formed under these conditions surrounds the mineral grains and clasts of the till and, as it dries, it firmly cements the particles together into a hard mass.

In the area of concrete-like till, the till below the groundwater table is of normal compactness. This is because the amount of free oxygen was insufficient to oxidise the iron into trivalent ferric iron. It is very likely that the pyrite is weathered and that the sulphide has been altered to sulphate, but nevertheless the iron remains as divalent ferrous iron, which is readily soluble in acidic groundwaters. Oxidation from ferrous to ferric iron does not take place until the groundwater is exposed to atmospheric oxygen from the atmosphere. Then the ferric iron precipitates as a brown substance that often occurs around springs where groundwater reaches the surface.

As a geological phenomenon, cementation of the surface part of till is quite young. In the Northern Ostrobothnian Schist Area, it has only been active during the last 2000 years while the area has been above the surface of the Baltic Sea. It is likely that, because of land uplift, cementation is still active at the western end of the schist area. Here, the coast at Haukipudas is at present emerging from the sea.

The hardness of the cemented till increases construction costs because it is not possible to excavate or remove this material with normal excavating equipment. In areas where the bedrock contains sulphide-bearing schists of the type described here (e.g. in eastern and in southwestern Finland), the fact that there is a potential risk of additional costs incurred by concrete-like till should be taken into account during the planning of civil engineering projects.

\section{REFERENCES}

Aario, R. \& Forsström, L. 1979. Glacial stratigraphy of Koillismaa and North Kainuu, Finland. Fennia 157: 2, $1-49$. 
Ahtonen, N. 1996. Pohjois-Pohjanmaan liuskejakson mustaliuskeiden geokemia, mineralogia ja petrofysiikka malminetsinnän kannalta. Unpublished master's thesis, University of Oulu, Department of Geology. 78 p. (in Finnish)

Carlson, L. \& Loukola-Ruskeeniemi, K. 1998. Raskasmetallien pidättyminen rautasaostumiin malmiesiintymien ja kaivosten ympäristössä. Summary: Fixation of heavy metals in iron precipitates around ore deposits and mines - a pilot study in eastern Finland. Vuoriteollisuus - Bergshanteringen 3/1998, 37-41.

Hirvas, H. 1991. Pleistocene stratigraphy of Finnish Lapland. Geological Survey of Finland, Bulletin 354. 123 p.

Honkamo, M. 1986. Haukipudas. Geological map of Finland $1: 100$ 000, Pre-Quaternary rocks, Sheet 2533. Geological Survey of Finland.

Honkamo, M. 1988. Haukiputaan ja Kiimingin kartta-alueiden kallioperä. Summary: Pre-Quaternary rocks of the Haukipudas and Kiiminki map-sheet areas. Geological map of Finland 1 : 100 000. Explanation to the maps of Pre-Quaternary rocks, sheets 2533 and 3511 . Geological Survey of Finland. 46 p.

Honkamo, M., 1989. Pohjois-Pohjanmaan vulkaniitit. Summary: Volcanic rocks in northern Ostrobothnia. Geological Survey of Finland, Report of Investigation 89. 46 p.

Korkiakoski, E.A., Kvist M., Nenonen, J., Pänttäjä, M., Rossi, S., Pernu, T., \& Vanhanen, E. 1995. Integrated exploration of massive sulphide deposits and gold within the Palaeoproterozoic Northern Ostrobothnia volcano- sedimentary belt. In: Precambrian '95: International Conference on Tectonics \& Metallogeny of Early/Mid Precambrian Orogenic Belts, August 28 to September 1, 1995. Program and abstracts. Montréal: Université du Québec, 173.

Kurimo, H. 1979. Deglaciation and early postglacial hydrography in northern Kainuu and Peräpohjola, northeast Finland. A glacial morphology study. Joensuun korkeakoulun julkaisuja - Publications of the University of Joensuu B II 10. 64 p.

Maaperäosaston kartoitus- ja tutkimusryhmä 1976. Kenttätyöopas No. 1. Maaperäkartoitus. Geologinen tutkimuslaitos. 22 p. (in Finnish)

Nenonen, K. 1995. Pleistocene stratigraphy and reference sections in southern and western Finland. Geological Survey of Finland, Regional Office for Mid-Finland, Kuopio. 95 p.

Saarenketo, T. \& Tammela, K. 1987. Moreeniluolia Kaamasen tiellä. Geologi 39, 44-45. (in Finnish)

Seel, F. 1965. Grundlagen der Analytischen Chemie, 4. Auflage, Verlag Chemie GmbH, Weinheim. 348 p.

Sutinen, R. 1992. Glacial deposits, their electrical properties and surveying by image interpretation and ground penetrating radar. Geological Survey of Finland, Bulletin $359.123 \mathrm{p}$.

Vasunta, E. 1984. Jolosharju. Unpublished master's thesis, University of Oulu, Department of Geology. 92 p. (in Finnish) 